Article

\title{
Achieving Conservation and Equity amidst Extreme Poverty and Climate Risk: The Makira REDD+ Project in Madagascar
}

\author{
Laura Brimont ${ }^{1,2, *}$, Driss Ezzine-de-Blas ${ }^{1}$, Alain Karsenty ${ }^{1}$ and Angélique Toulon ${ }^{3}$ \\ 1 CIRAD, Campus international de Baillarguet, Montpellier 34398, France; \\ E-Mails: ezzine@cirad.fr (D.E.-B.); alain.karsenty@cirad.fr (A.K.) \\ 2 AgroParisTech, 16 rue Claude Bernard, Paris 75231, France \\ 3 Department of Applied Economics, Université Montesquieu Bordeaux IV, Avenue Léon Duguit \\ Pessac 33608, France; E-Mail: angelique.toulon@gmail.com
}

* Author to whom correspondence should be addressed; E-Mail: laura.brimont@cirad.fr or lbrimont@outlook.fr; Tel.:+33-(0)-622-480-270.

Academic Editors: Arild Angelsen and Eric J. Jokeloa

Received: 6 September 2014 / Accepted: 6 March 2015 / Published: 18 March 2015

\begin{abstract}
Achieving forest conservation together with poverty alleviation and equity is an unending challenge in the tropics. The Makira REDD+ pilot project located in northeastern Madagascar is a well-suited case to explore this challenge in conditions of extreme poverty and climatic vulnerability. We assessed the potential effect of project siting on the livelihoods of the local population and which households would be the most strongly impacted by conservation measures. Farmers living in hilly areas must resort to slash-and-burn agriculture (tavy) since a combination of topographic and climatic constraints, such as cyclones, makes permanent rice cultivation very difficult. These are the people who suffer most from conservation-related restriction measures. For practical reasons the project, unfortunately, did not target these farmers. The main focus was on communities with a lower cyclonic risk that are able to practice permanent rice agriculture in the lowlands. To reduce deforestation without violating the principles of equity, REDD+ projects in Madagascar need to better target populations facing high climatic risks and invest in efforts to improve the farmers' agricultural systems.
\end{abstract}

Keywords: Madagascar; conservation; REDD+; equity; climatic risk; agriculture 


\section{Introduction}

Forest resources support the livelihoods of over a billion of the world's extremely poor people [1,2]. Many of them practice slash-and-burn agriculture, which is considered as a major driver of deforestation in tropical forest-agriculture frontier areas [3-5]. Hence, one of the key issues in forest conservation concerns its impact on the livelihoods of poor local agricultural communities. Conservation measures entail costs and benefits for the local population [6,7], which raises the question of the distributive equity of conservation projects [8-10]. Madagascar offers a good example of the trade-offs between poverty and conservation, as it is one of the poorest countries in the world - ranked 151st out of 187 countries according to the 2012 Human Development Index, although its abundance of endemic species makes it an outstanding biodiversity hotspot [11]. Madagascar is also one of the countries most vulnerable to the vagaries of climate [12]; the northeastern coast, for instance, is strongly affected by the yearly cyclones originating in the Indian Ocean. Rural populations are vulnerable due to frequent heavy rains and flooding, and their exposure to this form of climate risk can explain the poverty traps observed [12].

Madagascar is among the top ten countries in the list of countries receiving aid for environment protection from the international community [13]. However, this has not protected Malagasy forests against the threat of deforestation: from 2000-2010, Madagascar recorded an annual loss of close to 44,000 hectares of natural forests, i.e., $0.5 \%$ per annum [14]. In rural areas, forests were sacrificed to slash-and-burn agriculture, known as tavy [15]. The high population growth rate (about 3\% per year), lack of economic alternatives, and low public investments in the rural and agricultural sectors have contributed to the growing need for new agricultural lands, and explain the high deforestation rates. Climate also plays a major role in deforestation. Since upland plots are less likely to destruction from floods associated with cyclonic events than lowlands, farmers living in areas exposed to cyclonic risk are more prone to clear the forestlands to practice slash-and-burn agriculture [16,17]. Limited political, human and financial resources have prevented the Government of Madagascar from controlling the encroachment of agriculture on natural forestlands, although the burning of forests has been officially banned since 1881 [18].

In 2003 the Government of Madagascar decided to triple the size of the protected area to strengthen the enforcement of forest conservation measures. This means that $40 \%$ of the remaining natural forests were allocated protected areas [19] To persuade the local populations living at the edge or within the "newly protected areas" to participate in forest conservation, the Government, with the support of international cooperation agencies and non-governmental organizations (NGOs), implemented a large number of management transfer contracts (transferts de gestion). Management transfers were implemented under the 1996 GELOSE law (Gestion Localisée Sécurisée or Local and Secured Management) and the subsequent 2001 GCF (Gestion Contractualisée des Forêts or Contractualized Forest Management) decree. Management transfers follow the rules of patrimony management (gestion patrimoniale) [20,21] and common property resources theories [22], both of which assume that renewable natural resources can only be sustainably exploited if local communities have long-term rights and management responsibilities [23]. Community management is therefore an alternative to (mandatory) centralized management. The GELOSE law allows local communities to obtain recognition of their customary rights to natural resources through a contract between the state, which 
continues to own the land, the community, represented by an ad hoc legally recognized local institution called VOI (Vondron'Olona Ifotony), and the municipality. The local community is supported by an environmental mediator who facilitates its relations with the administration. The GCF decree, more commonly used than the GELOSE law, simplifies the conditions of management transfers by excluding the municipality from the contract, eliminating the environmental mediator, and reducing the emphasis on tenure security. Critics argue that these measures could decrease the long-term empowerment of local communities [24,25]. In any case, the community is required to respect the management plan, which theoretically it has defined. The plan defines zones with different land use rights, including strictly forest conservation zones, with no land use or commercial use rights. In the other zones, commercial use and harvesting rights for timber and non-timber products are strictly regulated, and households have to pay a harvesting fee. Slash-and-burn is only permitted on fallows and households have to pay a tavy fee $[25,26]$. Respect for the newly protected areas and associated management transfers, has brought about a major change for the neighboring populations as a result of stricter government enforcement.

In 2012, the Makira Natural Park in northeastern Madagascar completed the necessary administrative requirements and became the first 'newly protected area'. The Wildlife Conservation Society (WCS), the international NGO which had been funding conservation activities in Makira since 2003, signed a contract with the government to manage the area [27]. Moreover, to obtain funding for the Natural Park, WCS has been participating in the REDD + mechanism, which has grown significantly since 2008 when the Government of Madagascar joined the World Bank Forest Carbon Partnership Facility (FCPF). WCS helped the Government of Madagascar sell 150,000 carbon credits in 2004 and 2008 from the Makira Natural Park, through the intermediary of the Centre for Environmental Leadership in Business (CELB) [28]. Carbon credit sales generated US\$ 700,000 that have been invested in conservation and development activities. In 2014, the Government of Madagascar in partnership with WCS sold 95,000 additional Makira Natural Park carbon credits [29].

Given such a unique and high degree of integration in the REDD+ mechanism in Madagascar, the Makira project is an appropriate case study to inform the REDD+ debate, in particular about the challenge of combining conservation, poverty alleviation, and equity. There are different principles of equity with regard to the distribution of costs and benefits [6,30]; we adopted Rawls' principle of difference as the defining criterion of equity, considering that "social and economic inequalities are to be arranged so that they are both to the greatest benefit of the least advantaged (...)" [31] (p. 72). We assumed that communities are heterogeneous entities [25,26], and that individuals within communities had differentiated economic profiles. We argued that the most disadvantaged are the households that are the most reliant on forest resources, and consequently the most constrained by restriction measures. Moreover, since forest resources are used as a safety net to cope with climate disasters [16,17], we hypothesize that households that are the most exposed to climatic risk are also the most reliant on forest resources.

Our study assesses conservation and development activities being implemented in Makira in the light of such equity principles, taking into account the social-environmental diversity reflected in the Makira project. In particular, we explore how conservation and development activities currently implemented by WCS in the Makira protection zone affect the people likely to be the most affected by the conservation restrictions, i.e., those who are the most reliant on tavy. We answered this question by 
assessing the development and conservation activities implemented in the Makira protection zone, and by identifying the factors that determine the reliance of households on tavy.

The paper is structured as follows: in the methods section, we explain our conceptual framework and present the Makira general context including the characteristics of the survey zones and our research methods. Under the results section we describe the implementation of WCS conservation and development actions, especially in the survey zones. Thereupon, we analyze the farmers' land-use patterns and their perception of the probable evolution of their agricultural systems, which confirmed their feeling that tavy is the agricultural system most seriously affected by conservation restrictions. We then identify the determinants of households' reliance on tavy using a linear regression model. The concluding discussion addresses the implications of the WCS program with regard to distributive equity, as well as some practical measures to overcome inequity and improve targeting of the most affected population.

\section{Methods}

\subsection{The Study Area}

Makira humid forests are located in the mountainous landscape of northeastern Madagascar (Figure 1). The highest hills (1200 m above sea level lie on the western side, while the forest extends along a narrow alluvial flat on the eastern side [32]. The eastern side is very rainy (approximately $3500 \mathrm{~mm}$ per year) while the western side is sub-humid to dry (1200 $\mathrm{mm}$ per year). The area, especially the eastern part, is affected by cyclones originating in the Indian Ocean [33]. Since 2000, three cyclones have stricken the Makira forests: Hudah (2000), Gafilo (2004), and Indlala (2007) (Figure 1). The Makira project zone covers 707,643 hectares, which encompasses the Makira Natural Park (372,470 hectares), and the surrounding protection zone (335,173 hectares), where management transfers are allocated (Figure 1). About 9800 households live in the Makira project zone (2009 estimate): $97 \%$ live in the protection zone; the remaining 3\% live inside the Makira Natural Park [34]. For the survey, we identified four zones (I, II, III, and IV) according to deforestation trends and the degree of investments in development activities (see survey characteristics section for further details). The majority of households living in the survey zones belong to the Betsimisaraka ethnic group. Subsistence agriculture is the main economic activity, with rice being the staple food.

Farmers use three agricultural systems: permanent rice cultivation on lowlands (horaka), slash-and-burn rice cultivation on forested slopes (tavy), and perennial and semi-perennial cropping (tanety). Tavy is a shifting agriculture system where primary and secondary forests are cleared, left to dry, burnt, and then cropped. Rice is generally associated with crops such as maize, pumpkin, legumes, etc. and may be followed by a tuber crop like yam or cassava. According to our data, $84 \%$ (standard error $=2 \%$ ) of tavy crop production is grown for home-consumption. After one or two annual harvests - farmers crop rice once or twice on the same tavy plot depending on the soil fertility, the farmers leave the field to allow regrowth of the secondary forest, and move on to clear other plots. In Makira forests, as in other parts of Madagascar, the average fallow period has become much shorter during the last decades. In the Ranomafana Andringitra forest corridor, for instance, the length of fallow has dropped from $8-15$ years around the 1970 s to $3-5$ years in the 2000s [35]. In the 
Makira region, the fallow period lasted an estimated 5-7 years at the beginning of the 1990s [36], while our field assessment indicated a decrease to 4-5 years. Fallow periods are growing shorter because of increased land pressure, mainly caused by high population growth and forest clearing restrictions.

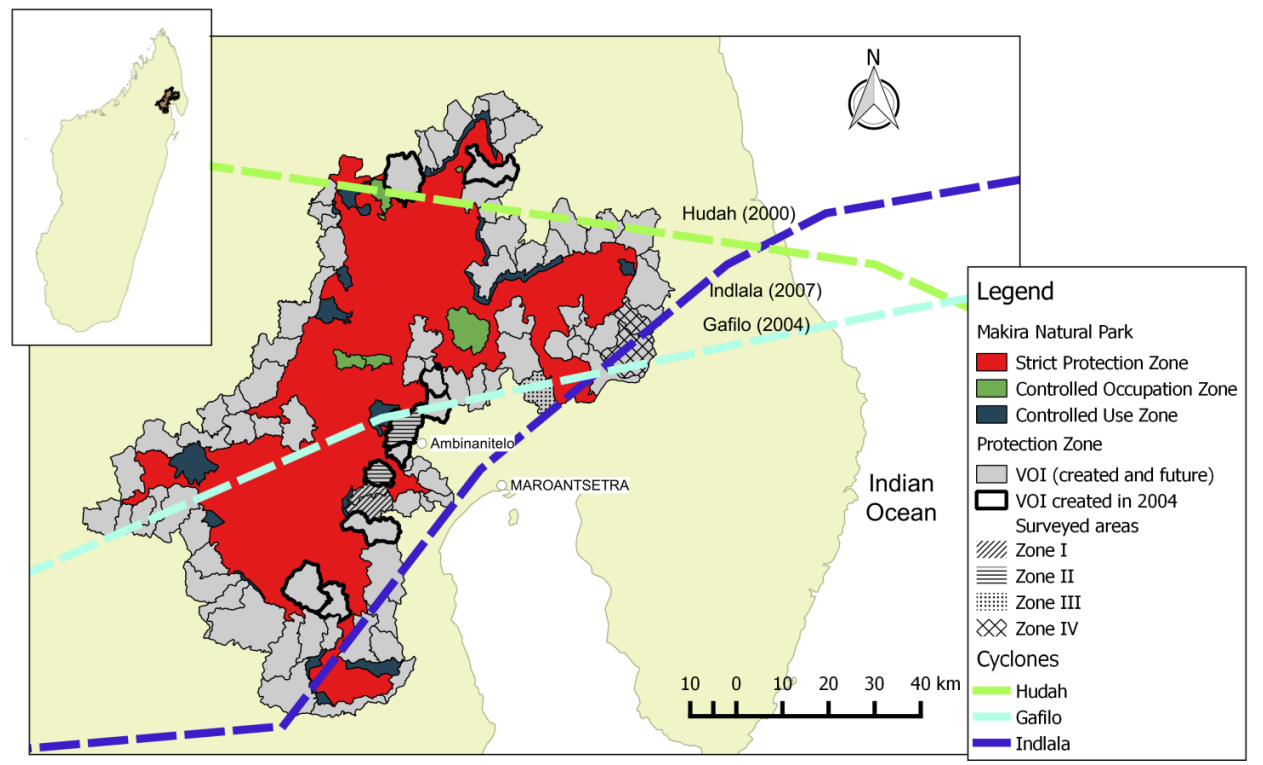

Figure 1. Makira project zone and survey areas in the protection zone.

None of the fallow species are able to withstand the 4-5 year slashing frequency: after three or four cycles following primary forest deforestation, herbaceous species start dominating the fallows, and soil fertility drops to so low a level that farmers abandon the old deforested fields and clear new patches of primary forest [37].

On tanety, perennial crops, for example vanilla, coffee, cloves, and other cash crops, are grown together with subsistence crops, e.g., banana and semi-perennial crops like roots and tubers. Production from tanety fields represents more than half of the entire agricultural production (Figure 2); $59 \%$ (standard error $=4 \%$ ) of the production from tanety is for home-consumption. The major cash crops differ from one region to the next region: villages located in the Maroantsetra district grow mainly cloves, while villages in the Antahala district cultivate vanilla. This difference comes from the colonial legacy. In the French administration's territorial agricultural system, the towns of Mananara, Fénérive, and Maroantsetra cultivated cloves, while the towns of Antahala, Andapa, and Sambava grew vanilla [38]. Households in eastern zones rarely grow cloves, even though cloves are currently much more profitable than vanilla: in 2012, in our survey area, the farmgate buying price for cloves was US\$ $6 \mathrm{~kg}$, while the price for green vanilla was US\$ 1-2 kg. Because vanilla and clove crops require several years to reach maturity and start producing, and because information on the food market is not readily available, farmers are not able to adapt their crop choices quickly and easily in response to price volatility.

Farmers breed poultry, and they rear zebu cattle to plough the permanent rice fields. Zebus are also a source of savings, and are sacrificed in traditional rituals to honor ancestors [39]. Off-farm activities include farm labor, cash crop traders, grocery sellers, etc. Households also practice artisanal mining and small-scale logging in Somisika, a village in the southeast zone where a former conservation 
project led by the NGO WWF supported the creation of a VOI with commercial logging rights. Commercial logging is now forbidden in the territories under community management, yet it is still practiced in Somisika.
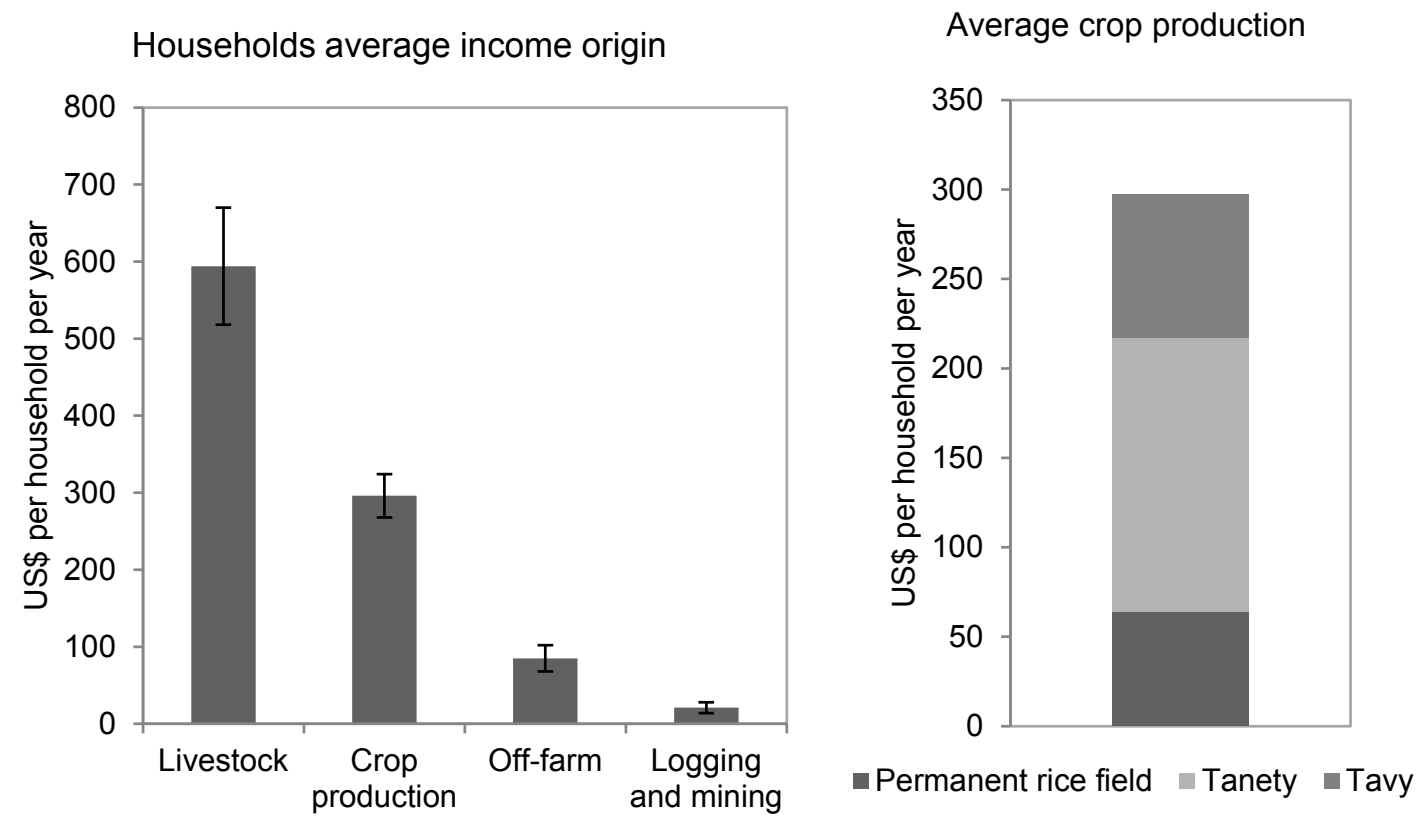

Figure 2. Origin of average income per household in the survey sites $(N=160)$.

\subsection{Makira Natural Park Conservation Measures}

Although the Makira forests enjoyed legal protection before the introduction of the project since $60 \%$ of the lands were already classified as "protected area" [29], WCS clarified and toughened the rules concerning forest management and protection. Inside the Makira Natural Park, there are three zones: the strict protection zone, with no commercial or subsistence uses allowed; the controlled occupation zone, mostly non-forested, where people live and where subsistence activities are allowed; and the controlled-use zone, where the use of natural resources for subsistence is authorized (Figure 1). Around the Makira Natural Park, local communities which have contracted GCF management transfers are responsible for the protection zone. Each management transfer territory includes a conservation zone where no harvesting or removal is allowed, and an area where forest resources may be used for subsistence, according to a management plan. Local communities are prevented from using primary forestland to extend their agricultural activities, and their use of forest resources is restricted to home-consumption only.

The implementation of conservation rules established under management transfers entails two types of costs for local communities, i.e., revenue losses and soil fertility depletion. Households can lose off-farm revenue as they can no longer practice artisanal mining and small-scale logging. Besides, they are likely to experience a decrease in the agricultural output from tavy fields, since the ban on clearing additional forestlands leaves them no choice but to constantly recultivate the same lands. The people who are the most affected by conservation restrictions are those who rely most on tavy, mining and small-scale logging. 


\subsection{Conceptual Framework}

We define the reliance of households on tavy as the share of production from tavy in the total agricultural production. We choose not to consider the reliance of households on mining and logging activities since these activities are very mobile and can more easily escape the control of WCS and the forest administration services; consequently they are less likely to be affected by conservation restrictions. We use five variables measured by seven indicators to capture the determinants of household reliance on slash-and-burn agriculture or tavy (Figure 3). These variables are divided into three categories: economic, cultural, and environmental.

Economic variables include land access, labor endowment, and income diversification. According to Ribot and Peluso [40], land access is determined by the social endowments of the households. We use age and geographic origin indicators to measure the social endowments that determine land access. We expect land restrictions to affect young households and migrants first and foremost since the Malagasy rural society is organized through lineages under the authority of the oldest individuals [41], which means that young households have to rely on the oldest members of the community for access to land. Here, as elsewhere in Madagascar [42], land access for migrants is controlled by the natives (tompontany, or landlord). In our analysis, a migrant is a head of household who was not born in the village and whose parents are not natives of the village. Regarding labor endowment, our main indicators are ownership of the zebu used to plough the permanent rice fields, and number of working members. We expect that the households that do not own zebu are likely to be more reliant on tavy, since they are unable to plough the permanent rice fields. As slash-and-burn agriculture allows farmers to maximize labor in places where land is more readily available than labor, we presume that households with fewer working members will probably rely more heavily on tavy. We included income diversification in our economic variables to assess households' reliance on tavy since rent diversification, i.e., crop and income diversification, in the rural areas provides an impeccable alternative strategy to protect against climatic risks $[42,43]$.

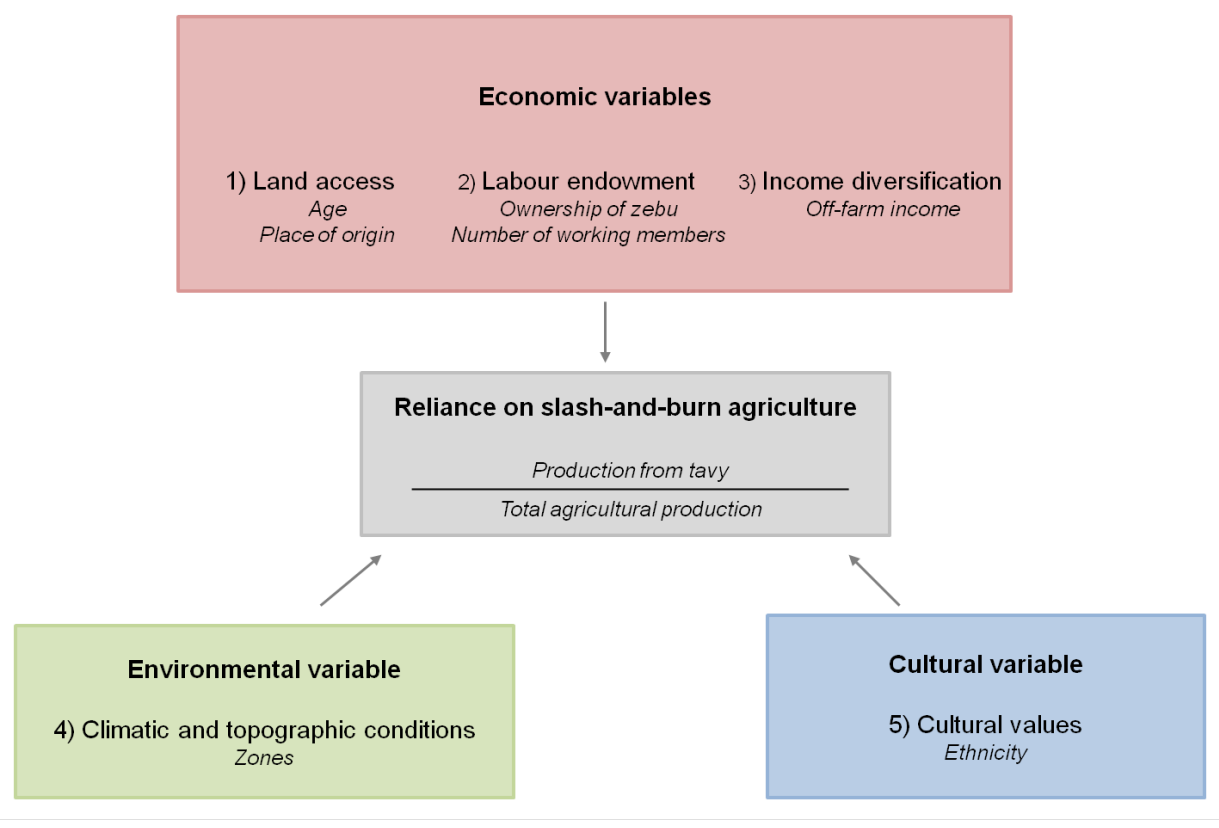

Figure 3. The determinants of household reliance on slash-and-burn agriculture. 
We added a cultural variable under tavy dependence to test for the culturally-based reliance on tavy of the Betsimisaraka [16]. We expect Betsimisaraka households to be more reliant on tavy than others. Finally, we considered environmental factors, since slash-and-burn agriculture depends on topographic and climatic conditions. Slash-and-burn agriculture is better suited to hilly landscapes than permanent rice cultivation, which requires flat land. As noted in the introduction, slash-and-burn agriculture is also better suited to cyclone-prone areas. Figure 1 shows that the eastern end of the Makira project zone is the entry point of cyclones, which means that the households living in the eastern part of the Makira forests (zone IV) face the hardest climatic constraints. The eastern part is also where the land has the steepest sloping landscape (Table 1).

\subsection{Survey Characteristics}

Our survey was conducted in two stages. The first stage was composed of qualitative interviews with the Makira project coordinators to make a preliminary evaluation of the project's achievements, to identify the local vocabulary used by farmers, to test the household survey, and to select the survey communities whose remoteness made them difficult and time-consuming to reach. The agricultural systems in the eastern side of the Makira forests are more likely to be affected by the conservation restrictions than those of the western side where farmers clear forestland more for cattle raising than for slash-and-burn agriculture. Consequently, we chose to visit the communities located in the protection zone of the eastern side (Figure 1). Since the western side of Makira does not have the same ecological, agricultural, and economic characteristics as the eastern side [32], our statistical analyses cannot be extrapolated to the entire project zone. We did not visit the communities living in the controlled occupation zones inside the protected area since WCS has not invested in these zones [44]. The oldest VOIs (created in 2004) such as the VOIs classified in zone II (Figure 1) benefitted from most development activities. On the other hand, some communities like the ones in zones I and IV did not benefit from management transfers (Table 1).

Table 1. Main characteristics of the field survey sites.

\begin{tabular}{|c|c|c|c|c|c|}
\hline \multicolumn{2}{|c|}{ Zones } & $\mathbf{I}$ & II & III & IV \\
\hline \multicolumn{2}{|c|}{ Villages/VOIs names } & $\begin{array}{l}\text { Andongona } \\
\text { Vinanibe }\end{array}$ & $\begin{array}{c}\text { Anjiahely } \\
\text { Marovovonana }\end{array}$ & Somisika & $\begin{array}{l}\text { Antsahantitra } \\
\text { Amparihimena }\end{array}$ \\
\hline \multicolumn{2}{|c|}{ Number of households } & 242 & 913 & 200 & 271 \\
\hline \multicolumn{2}{|c|}{ Number of households interviewed } & 27 & 33 & 40 & 60 \\
\hline \multicolumn{2}{|c|}{ Date of creation of VOIs } & No VOI & 2004 & 2010 & No VOI \\
\hline \multirow{3}{*}{$\begin{array}{c}\text { Deforestation } \\
\text { Rate }(\%)\end{array}$} & 1995-2000 & 0.1 & 0.3 & 0.9 & 1.1 \\
\hline & $2000-2005$ & 2.0 & 0.8 & 1.6 & 1.8 \\
\hline & $2005-2010$ & 2.8 & 4.4 & 0.2 & 0.8 \\
\hline \multicolumn{2}{|c|}{$\begin{array}{l}\text { Accessibility from WCS's office } \\
\text { (Maroantsetra) }\end{array}$} & Difficult & Easy & Difficult & Very difficult \\
\hline \multicolumn{2}{|c|}{ Countryside characteristics } & Hilly & Hilly & Hilly & Very hilly \\
\hline \multicolumn{2}{|c|}{ Exposure to cyclones } & Less exposed & Less exposed & Exposed & Very exposed \\
\hline
\end{tabular}

The territories of the Vondron'Olona Ifotony (VOI) correspond to the villages; The deforestation rate is expressed as the percentage of forestland lost in the survey site compared to the area of forestland remaining in the survey site; Sources: Wildlife Conservation Society (WCS) and authors. 
The second stage of our survey consisted in household semi-structured interviews. Fieldwork was carried out in June and September 2012. We started with framed qualitative interviews with one or two key informants to assess the general social-economic conditions and conservation project achievements at the village level. The household questionnaire assessed households' reliance on tavy through the indicators defined in Figure 3. We captured farmers' perceptions of the impacts of conservation restrictions on their agricultural systems using open questions. We asked the farmers if they had perceived any change in their agricultural activities and, in case of a positive answer, we asked when this change occurred and what the specific reasons were. We also asked which categories of land (tavy, tanety, permanent rice fields) and which aspects of the agricultural system (yield, fallow length, land access) had changed. Because there was no population census, we selected the households using a non-probability sampling technique, i.e., we interviewed the heads of the household who were at home when we visited and who were willing to respond to our questions. We interviewed 160 households, i.e., a sampling rate of $10 \%$. The sampling rate is unevenly distributed across villages (Table 1), as we spent less time in each village during the first field mission - when we visited villages in zones I and II-because of disastrous weather conditions. Statistics were performed using RStudio software.

\section{Results}

\subsection{WCS Conservation and Development Activities in Makira Forests}

Since it started in 2003, the annual Makira project budget has been between US\$ 600,000 and US\$ 800,000 [29]. Considering the size of the project zone, this amounts to about one dollar per hectare per year. Currently one WCS agent is responsible for 525 households; the WCS plans to reach a ratio of one agent for 221 households, i.e., more than double its current supervisory capacity (Makira community coordinator, personal communication, 2012). The overall conservation and development program in Makira can be divided in four categories: (i) ensuring the conservation of Makira forests through the creation of the protected area; (ii) improving natural resources governance in the protection zone through the creation of management transfers; (iii) supporting livelihoods of local populations, and (iv) raising environmental awareness. Following the national rules on the creation of a new protected area and the World Bank's environmental and social safeguards policies, WCS has implemented safeguard activities dedicated to the "Project Affected People" (PAP) [45]. We did not assess the equity of the safeguard activities since they were implemented after we had completed our fieldwork. During our survey, we observed that the local population knew the exact location of the boundaries of the protected area, even though there were no physical markers. The presence of WCS staff in the field symbolized the existence of a protected area: people identified WCS with the state, using the word fanjakana (authority) for both the state and WCS. Land use restrictions are periodically monitored by mixed patrols composed of WCS staff, forest rangers, and law enforcement officers. This is a major change for the population, as many parts of the Makira zone are far from any city and previously enjoyed the "absent presence of the State" [46] (p.4), whereas now people express a "fear of the law". 
In the protection zone, WCS is improving land governance by creating management transfers. The first ten management transfers made in 2004 concerned communities that are easily accessible from Maroantsetra, where the WCS regional head office is located (Figure 1). By 2012, 45 management transfers had been completed out of a total of 84 planned. At the time of our survey, VOIs in the zone of study had been operational from one to eight years. The communities that refused to enter the management transfer system, such as the communities in zone I, argued that management transfers entailed more costs than benefits because of forest clearing restrictions. Community involvement in VOI was not the same everywhere. Some VOIs have monthly meetings, conduct ecological monitoring, and collect fees for timber harvesting and slash-and-burn authorizations. Other less active VOIs only meet a few times per year, have trouble in collecting forest management fees, and are not trusted by the community $[25,47]$.

Development activities for agricultural support, health, education, and water conveyance are concentrated in the ten oldest VOIs, created in 2004 (Figure 1). The 2012 budget was US\$ 80,000, what represents about US\$ 8 per household. Beekeeping activities were tested in some areas but did not produce satisfactory results because of the climate [48].

Agricultural support activities emphasize training in improved rice-growing techniques and the development of permanent rice fields through the construction of small-scale dams and the use of plowing tools (Table 2). Ten small-scale dams have been constructed to date, mainly in areas close to Maroantestra. WCS experimented with activities aimed at improving fertility in the slash-and-burn agricultural system by introducing permaculture; these activities are no longer being funded. According to our survey results, the number of households that benefitted from agricultural support (training or dams) does not exceed $15 \%$ in zone II, the zone that received the most support (Table 2).

Table 2. Conservation and development activities in the survey zones.

\begin{tabular}{|c|c|c|c|c|}
\hline Zones & $\mathbf{I}$ & II & III & IV \\
\hline $\begin{array}{c}\text { Number of interviewed } \\
\text { households }\end{array}$ & 27 & 33 & 40 & 60 \\
\hline Agricultural activities & $\begin{array}{l}\text { No agricultural } \\
\text { activities }\end{array}$ & $\begin{array}{l}\text { Small-scale dams Training } \\
\text { (irrigated rice and tanety) } \\
\text { Clove cultivation nursery }\end{array}$ & $\begin{array}{l}\text { No } \\
\text { agricultural } \\
\text { activities }\end{array}$ & $\begin{array}{l}\text { No } \\
\text { agricultural } \\
\text { activities }\end{array}$ \\
\hline $\begin{array}{l}\text { Number of } \\
\text { beneficiaries }\end{array}$ & $\begin{array}{l}\text { Training irrigated } \\
\text { rice: } 2 \text { (in } \\
\text { another VOI) }\end{array}$ & $\begin{array}{c}\text { Small-scale dams: } 5 \\
\text { Training irrigated rice: } 4 \\
\text { Training tanety: } 1\end{array}$ & 0 & 0 \\
\hline Basic services & $\begin{array}{l}\text { Access to basic } \\
\text { health services }\end{array}$ & $\begin{array}{c}\text { Access to basic health } \\
\text { services } \\
\text { Water Pump } \\
\text { Building a school } \\
\text { Breakfast program } \\
\text { Reading training for adults }\end{array}$ & $\begin{array}{l}\text { Training of a } \\
\text { community } \\
\text { health agent }\end{array}$ & $\begin{array}{l}\text { No basic } \\
\text { services }\end{array}$ \\
\hline
\end{tabular}


Table 2. Cont.

\begin{tabular}{ccccc}
\hline Zones & I & II & III & IV \\
\hline $\begin{array}{c}\text { Number of } \\
\text { beneficiaries }\end{array}$ & 1 & $\begin{array}{c}\text { Breakfast program: } 1 \\
\text { Reading training: } 1\end{array}$ & 1 (the agent) & 0 \\
Forest restoration & No program & Clove cultivation nursery & No program & No program \\
$\begin{array}{c}\text { Number of } \\
\text { beneficiaries }\end{array}$ & 0 & 5 & 0 & 0 \\
$\begin{array}{c}\text { Audience rating of } \\
\text { radio program }\end{array}$ & $52 \%$ & $64 \%$ & $68 \%$ & $75 \%$ \\
\hline
\end{tabular}

Audience rating of the environmental radio program reflects the percentage of households interviewed that had listened to the Makira environmental radio program at least once. The number of beneficiaries is the number of interviewed households that benefit from the activity.

WCS also created tree nurseries to encourage the cultivation of cloves as a cash crop. The percentage of households that benefitted from tree nurseries is also around 15\% (Table 2). Regarding the improvement of basic services, WCS funded water pumps and the construction of a school. A breakfast program to distribute meals two or three times per week in some rural schools was also implemented with funding from the Australia's overseas aid program. WCS also received a US\$ 300,000 grant from Population Services International to improve mothers' and children's access to basic health services, including contraceptives and mosquito nets. Table 2 shows the number of interviewed households having directly benefitted from these activities; school-goers were not included.

Other development activities include the development of an ecotourism program and the construction of a microcredit bank in Ambinanitelo. According to a bank representative, 409 households have become members since 2008. Members are allowed to take out individual loans ranging from US\$ $80-800$. Access to microcredit services is still limited to the wealthiest individuals, since the bank charges a monthly fee of US\$ 2.5 , and members have to guarantee their loan with personal assets, for example a television set, and are required to have some savings. Finally, the WCS communication campaigns in schools and villages during field outreach missions contribute to increasing environmental awareness by discussing forest management rules and ecosystem services provided by the Makira forests. In addition, a weekly radio program is dedicated to the conservation of the Makira forests. It is proving to be effective since the number of households that listened to the radio program at least once is significant, even in the zones where there are no VOIs (Table 2).

\subsection{Land Access Patterns}

To improve our understanding of the profile of households in our survey zones, we analyzed patterns of their agricultural systems. Agricultural diversification is their main strategy: $57 \%$ of the interviewed households use permanent rice fields, tavy, and tanety, whereas $8 \%$ of households use only one type of agricultural system. Households who use two categories of land represent about one-third of the sample and are divided between those who use permanent rice and tanety fields (17\%), 
and those who use tanety and tavy fields (17\%). Interestingly, there are very few households who only cultivate permanent rice, or only cultivate the tavy fields (2\%). Access to tanety fields does not seem to be a problem, since almost all the households use these fields (92\%). On the other hand, $22 \%$ of households do not use the permanent rice fields and 20\% do not use tavy fields.

As previously explained, conservation restrictions prohibit the clearing of primary forests and limit access to agricultural lands. The most usual land use path for slash-and-burn agriculture is composed of a clearance-crop-fallow sequence (Figure 4, step 1). Another path involves the clearing of forestland to prepare a tanety field, where perennial crops are often mixed with the remaining trees, thus creating an agro-forestry system (step 2), or turning former tavy fields into tanety fields after one season of rice cultivation (step 3). Transformation into tanety fields may take place after a fallow period (step 4), or after a second or third cycle of tavy (step 1 followed by step 3).

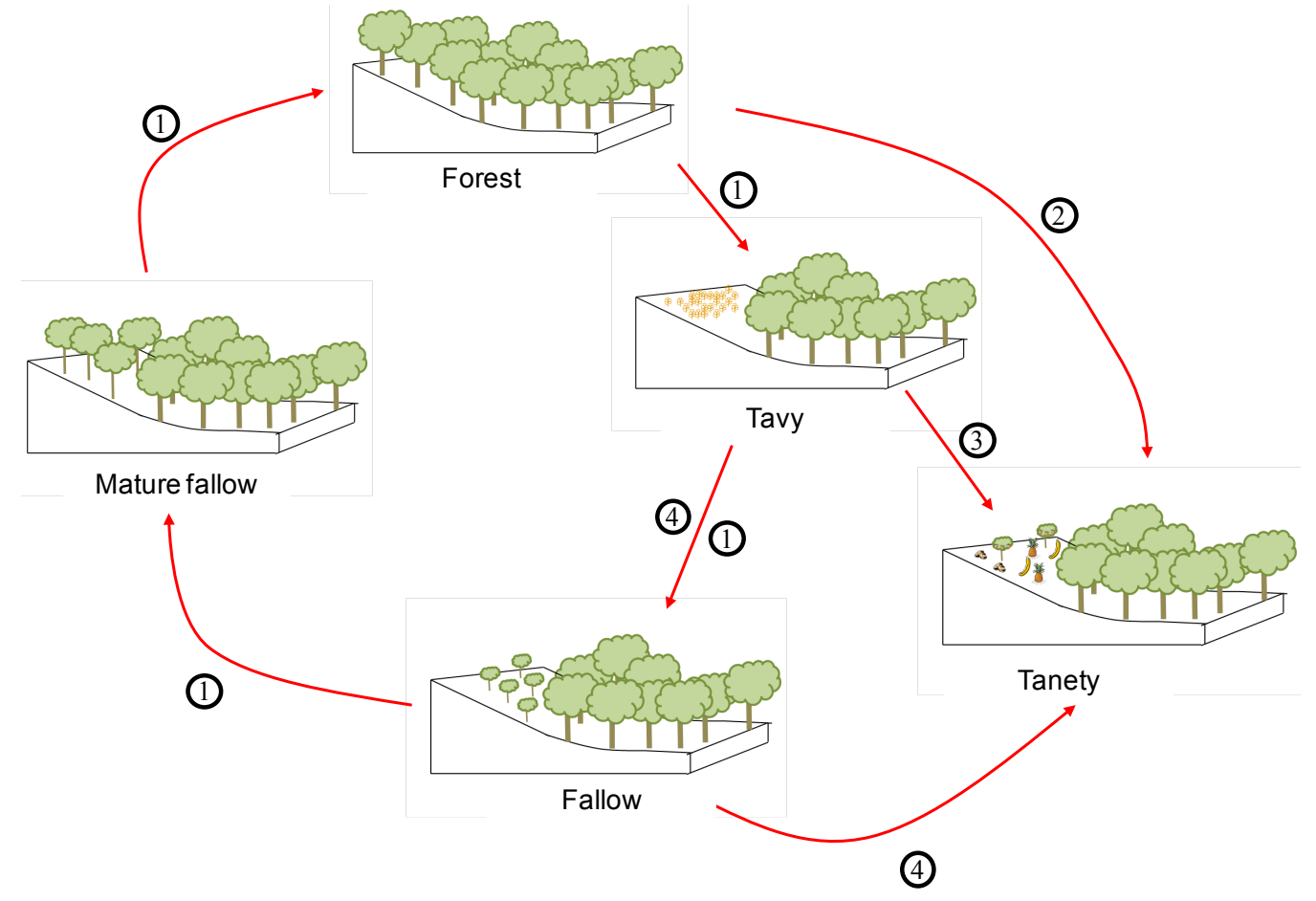

Figure 4. Land use change in the Makira project region.

We have seen that cleared forest areas can be used as both tavy and tanety fields but that clearing primary forests is now prohibited throughout the Makira forest. Yet nearly all the farmers use the tanety lands, which shows there is not a shortage of tanety fields at the time we conducted our survey. The reason may be that forest clearing is a less common way to obtain new agricultural land than inheritance and market-based access (purchase, sharecropping, and renting): in our survey, regardless of the agricultural system, only $10 \%$ of the new agricultural lands were obtained from forest clearing, while $64 \%$ was received through inheritance and $25 \%$ from market transactions. Fear of confessing to have cleared forestland might partly explain the low number of deforested plots in the total number of plots acquired in the survey.

To confirm that the ban on primary forest clearing has constrained access to tavy fields we asked households if they had perceived any changes in their agricultural systems; $25 \%$ of the farmers who practice tavy said that the implementation of conservation restrictions reduced access to tavy fields or 
made it more difficult. Conservation restrictions, however, seem to have had little impact on access to permanent rice fields: $7 \%$ of farmers in the survey said it was more difficult to find new plots because they are not allowed to clear new fields to plant rice under the tavy system and that more and more people want to crop the existing rice fields. Local farmers talk about the "revival of permanent rice fields". Conservation restrictions may indirectly increase the demand for permanent rice fields, which are already more in demand than the tavy fields. This is confirmed by the rental prices: the average rental price for permanent rice fields is US\$ 35/ha/year while it is only US\$ $25 /$ ha/year for tavy fields; both produce the same quantity of rice, 1 ton/ha (Anova, $F$-value $=2.70, p$-value $=0.1$ ).

\subsection{The Determinants of Reliance on Tavy}

We define reliance on tavy as the share of the total agricultural production coming from tavy. We tested what determined household dependence on tavy fields using a linear regression model whose independent variables include the seven indicators identified in our conceptual framework (Table 3). The estimation was based on 104 observations, since 56 of our 160 observations lacked data for at least one variable. The Variance Inflation Factor (VIF) value did not show any collinearity among independent variables (vif function, package car, Rstudio version 0.98.507). We corrected heteroskedasticity, using the Sandwich estimator (coeftest function, package sandwich, Rstudio version 0.98.507).

Table 3. Results of linear regression reliance on slash-and-burn (tavy) subsistence crops.

\begin{tabular}{|c|c|c|c|c|c|}
\hline \multicolumn{6}{|c|}{ Descriptive statistics } \\
\hline \multicolumn{2}{|c|}{ Dependent variable } & \multicolumn{4}{|c|}{ Independent variables } \\
\hline \multicolumn{2}{|c|}{$\begin{array}{c}\text { Reliance on tavy crops } \\
\text { Mean }=32 \% \\
(\text { standard error }=3)\end{array}$} & \multicolumn{2}{|c|}{$\begin{array}{c}\text { Age Mean }=40 \text { years } \\
(\text { standard error }=1 \text { ) } \\
\text { Number of working members } \\
\text { Mean }=2.5 \text { individuals } \\
\text { (standard error }=0.1) \\
\text { Off-farm income } \\
\text { Mean }=\text { US } \$ 117 \\
\text { (standard error }=28)\end{array}$} & Ethnic Betsimisa & $\begin{array}{l}\text { ants: } 18 \\
V: 48 \\
\end{array}$ \\
\hline \multicolumn{6}{|c|}{ Results } \\
\hline $\begin{array}{l}\text { Variables } \\
\text { Age }\end{array}$ & $\begin{array}{c}\text { Coefficient } \\
-0.004\end{array}$ & $\begin{array}{c}P \text {-value } \\
0.11\end{array}$ & $\begin{array}{l}\text { Variables } \\
\text { Migrants }\end{array}$ & $\begin{array}{c}\text { Coefficient } \\
-0.07\end{array}$ & $\begin{array}{c}P \text {-value } \\
0.40\end{array}$ \\
\hline Ethnic_others & 0.2 & $0.001 * *$ & Off_farm_income & $9 \times 10^{-8}$ & $0.007 * *$ \\
\hline Workers & 0.01 & 0.55 & I & -0.5 & $0.0 * * *$ \\
\hline Zebu_yes & -0.003 & 0.68 & $\begin{array}{l}\text { II } \\
\text { III }\end{array}$ & $\begin{array}{l}-0.5 \\
-0.4 \\
\end{array}$ & $\begin{array}{l}0.0 * * * \\
0.0 * * *\end{array}$ \\
\hline
\end{tabular}

Intercept $0.6\left({ }^{* * *}\right) ;$ Adjusted $R^{2}=0.37 ; * * * p<0.01 ; * * p<0.05 ; * p<0.1$.

Zone IV, the default, has significantly higher reliance on tavy crops. All things being equal, farmers belonging to ethnic groups other than Betsimisaraka have higher reliance on tavy. This finding, which is supported by other research in the area [49], challenges the claim sometimes made that the 
Betsimisaraka attach higher cultural value to the tavy than do other groups. Earning a higher off-farm income also reduces reliance on tavy while the age of the head of household, the number of working people in the household, the ownership of zebu(s), and the origin of the head of household were not statistically significant.

\section{Discussion}

\subsection{Impacts of Land Use Restrictions on Local Livelihoods}

Our results show that farmers living in zone IV rely most on tavy, which may be due to both topography and climate. These two constraints reinforce each other: on the one hand, eastern farmers live in a hilly landscape where lowlands for permanent rice fields are scarce. On the other hand, lowland plots are the most likely to be destroyed by floods during cyclonic events, which hit this zone with greater force than any other. It is significant that people living in this zone use the names of the cyclones as a marker of time. Topographic and climatic constraints thus limit agricultural choices to the tavy fields, as opposed to the diversification strategy observed in the other survey zones. Diversification of agricultural systems is an ancient strategy used in Madagascar to cope with climatic risk, as reported in a tale quoted by Pollini [17]: "When Kotofamandrika, the bird hunter, and Zahanary, the god princess, founded the Tanala kingdom (ethnic group that lived in rainforests), they sowed rice in a cleared forest. But birds and wild pigs destroyed the field. Then they sowed rice in paddy fields, but another kind of bird destroyed the harvest. Then they decided to sow on both kinds of fields on slopes and in bottom wet lands, so that the animals would not eat the rice" (p. 32).

Furthermore, the fact that the households that are the most reliant on tavy also have more off-farm activities (Table 3) suggests that diversified agricultural systems are being replaced by off-farm activities as a strategy to cope with climatic risks in the most vulnerable farming areas [50]. Zebu ownership does not condition tavy reliance since farmers in real need of zebu power to plough permanent rice fields can borrow or rent them. We may assume that the number of working members does not play a significant role in tavy reliance either since families help each other perform agricultural chores. The origin of the head of household does not condition tavy reliance either because access to land seems to depend more on the market than on family relationships. The existence of a land market is likely to facilitate access for migrants. With regard to the age of the head of household, our results suggest that the older ones may have earned a living from other activities, although we cannot state this as a fact since the variable is not sufficiently significant. Farmers' perceptions of the evolution of land use show that the combined pressure of slash-and-burn farming and forest protection will increase pressure on other land resources such as permanent rice plots. Increased demand may boost lowland purchase and rental prices and thus limit land access for the poorest households. Furthermore, switching to irrigated rice growing, does not necessarily lead to higher and better yields since labor is not the only input. Other factors such as soil fertility and cropping techniques must also be considered [51].

Another side effect of forest protection may be shorter fallow periods for existing tavy fields resulting in decreased fertility, as has been already seen in other areas where forest conservation and rice production compete $[34,52]$. Higher sale and rental prices for permanent rice fields are indicative 
of mounting land pressure. Finally, conservation restrictions may compromise the success of farmers' adaptive strategy to cope with climatic risk since they reduce agricultural diversification possibilities between permanent rice and tavy plots and between lowland and upland plots.

\subsection{Implications with Regard to WCS's Development Program}

Our analysis has brought out two important limitations to the WCS development program. First, development activities have mainly targeted easily accessible areas (Figure 1 and Table 2), leaving aside areas with high deforestation rates and climatic risks. Second, by building small-scale water management infrastructures, and providing training in improved rice growing techniques and materials for plowing, WCS targets farmers who already have access to permanent rice fields, without considering the question of how to use tavy to relieve the structural pressure on forest lands with high climate risks. To cope with these issues the project will need to (i) guide tavy-dependent households into permanent cropping activities, on both tanety and lowlands, and (ii) deal with the marginal areas. With regard to investing in permanent rice fields, there is broad agreement among environmental NGOs and donors that tavy practices can only be decreased if rice yields in the lowlands are increased [53,54]. The underlying assumption is that increasing yields from permanent rice fields will offset rice production losses caused by forestland access restrictions and incentivize farmers to concentrate on the more labor-intensive techniques used on the lowlands. One leading WCS funder, for instance, is promoting an improved rice-growing technique called the System for Rice Intensification (SRI) in other regions of Madagascar. Some REDD+ projects in Madagascar promote SRI as an alternative to slash-and-burn agriculture [51]. Yet, the improvement of permanent rice agriculture is hindered by the strategy of some donors who fear that investing in the infrastructure needed to improve agricultural output could contribute to untoward anthropogenic development. However, they do not factor in the positive downstream effects of such infrastructure on land conservation.

WCS for example, had difficulties in securing funding to construct the small-scale dams needed to improve irrigated rice cultivation in Makira, (WCS representative in Maroantsetra, personal communication, 2012) [48]. When considering the geographical allocation of conservation and development support, the remoteness factor appears to have played a major role. For example, the first communities to receive support for the creation of management transfers are the ones closest to Maroantsetra, where the WCS regional head office is located. This may be explained by the WCS cost-reduction strategy. In fact, the remoteness of the Makira project zone made it difficult for WCS to attract development actors, (WCS climate change technical advisor in Madagascar, personal communication) [29]. Concerning the controlled occupation zones inside the protected area, it seems that WCS deliberately chose not to invest in local development activities there, since the objective is to encourage people inside this area to leave their villages in the medium or long-term future [46].

In view of the above and considering the climatic risks and agricultural diversification alternatives, the Makira project does not seem to fully address the question of equity when siting development activities. The Makira project does not provide alternative off-farm earning opportunities, which could offset the losses stemming from forestland use restrictions, and does not allow farmers to substitute plot diversification for income diversification. To summarize, increasing agricultural yields in lowland 
plots without providing farmers with alternative risk management strategies in areas highly exposed to cyclones will not improve the livelihoods of the most vulnerable farmers. This strategy, according to our results, excludes nearly a quarter of the population, i.e., the households that do not have access to permanent rice fields.

\subsection{Improving Equity in Forest Conservation Projects through Climatic Risk Assessment: Lessons Learned}

To improve the livelihoods of the most vulnerable farmers in areas with high climatic vulnerability, development activities should target households that rely heavily on slash-and-burn agriculture. Defining areas prone to cyclones with limited possibilities of income diversification at the Makira-project level may help to direct the agricultural support to the most vulnerable households. Fine-tuned knowledge of the agro-economic dynamics in these zones may also help to identify the households that are most affected by the conservation restrictions. Currently farmers included in the "Project Affected People" (PAP) group who therefore will benefit from social safeguards activities, have been identified as those living in the controlled occupation zones [51], while the people living in the protection zone have been classified as minor PAPs. To increase project equity PAP households that live in these high- risk areas need to be identified.

Finally, to match the different farming profiles will require a variety of agricultural supports. There are no "silver bullet" solutions such as improving the sustainability of the farmers' land-use systems by focusing on a single component, like the productivity of permanent rice farming: the dynamics of agricultural systems have to be treated as a holistic system [55]. Farmers have no incentive to invest in costly agricultural techniques since they risk losing their whole crop with the following cyclone. The necessity to protect themselves against cyclonic risks also explains why farmers do not give up slash-and-burn rice cultivation to invest their labor in permanent rice growing. Conservation projects need to include risk management mechanisms that reduce the farmers' vulnerability and encourage them to adopt agronomic innovations as part of their strategy. In addition to agricultural training, the project could offer farmers low-cost private insurance in exchange for their commitment to stop tavy. The insurance could be indexed on the occurrence of a cyclone or drought to avoid the problems of adverse selection and moral hazard [56]. Project managers could also provide "investment-oriented" payments for environmental services (PES) to support agronomic innovation [57]. These payments would be linked to the farmer's commitment to respect the environmental management rules, and would cover the investment cost of agronomic innovations (training and inputs), with assurance that the new harvests would cover the opportunity cost of avoided deforestation, i.e., the cost of losing access to forest lands for agriculture and of giving up extractive activities like timber exploitation or mining.

\section{Conclusions}

This paper analyses the Makira REDD+ project implemented by WCS in northeastern Madagascar from the point of view of equity. By analyzing farmers' agricultural patterns and their perceptions of the evolution of agricultural practices we found that climatic and topographic constraints play a significant role in determining reliance on tavy, the slash-and-burn farming technique often practiced 
in hilly areas with high cyclonic risk. Conservation restrictions and cyclonic constraints mutually reinforce the vulnerability of the farmer's livelihood: by limiting access to new forestlands, conservation restrictions curtail agricultural diversification between lowland and upland plots, which is an adaptive strategy that farmers use to cope with climatic risk. We argue that WCS needs to better target its development support by considering all agricultural systems and include their role in managing climatic risk. Risk management and financial assistance could include insurance policies and PES-like schemes designed to contribute to agricultural advancement in the Makira conservation project area. Finally, the project illustrates the difficulties of adopting a project-based approach in a far-reaching conservation policy because of sporadic funding, multiple donors with different political strategies, and a limited budget to deal with challenging agricultural and conservation interlinkages. In 2014, the Government of Madagascar in partnership with WCS sold 95,000 carbon credits (worth US\$ 500,000) on the voluntary market [29]. This amount is probably not enough to meet the total financial needs of conservation activities and local development in the Makira project [51]. In the final analysis, closer coordination is needed between international aid dedicated to conservation programs and development programs to improve forest conservation through agricultural innovation [58]. Such coordination may increase the links between forest conservation and poverty alleviation.

\section{Acknowledgments}

The authors are very grateful to the team of the Wildlife Conservation Society (WCS) in Antananarivo and Maroantsetra for their collaboration. This study was funded by the PESMIX research program (Payments for environmental services: new panacea or auxiliary for environmental management?) of the French Research Agency (ANR 2010-Systerra 008.01). We wish to thank Laurent Gazull for his help in designing the research, and Guillaume Cornu for his help in the creating the map. We also acknowledge Elhyvie Razanamihanta, Francoeur Tambaza, Germain Rasolofonirina and Xavier Visseq for their support in data collection.

\section{Author Contributions}

Laura Brimont, Driss Ezzine-de-Blas and Alain Karsenty designed the field survey; Laura Brimont, Angélique Toulon and Alain Karsenty performed the field research; Laura Brimont analyzed the data; Laura Brimont and Driss Ezzine-de Blas wrote the paper.

\section{Conflicts of Interest}

The authors declare no conflict of interest.

\section{References}

1. World Bank. Sustaining Forests: A Development Strategy; The World Bank: Washington, DC, USA, 2004.

2. Angelsen, A.; Wunder, S. Exploring the Forest-Poverty Link: Key Concepts, Issues and Research Implications; CIFOR: Bogor, Indonesia, 2003. 
3. Geist, H.J.; Lambin, E.F. Proximate causes and underlying driving forces of tropical deforestation. BioScience 2002, 52, 143-150.

4. Malhi, Y.; Gardner, T.A.; Goldsmith, G.R.; Silman, M.R.; Żelazowski, P. Tropical forests in the Anthropocene. Ann. Rev. Environ. Res. 2014, 39, 125-159.

5. Godar, J.; Gardner, T.A.; Tizado, E.J.; Pacheco, P. Actor-specific contributions to the deforestation slowdown in the Brazilian Amazon. Proc. Nat. Acad. Sci. 2014, 111, 15591-15596.

6. McDermott, M.; Mahanty, S.; Schreckenberg, K. Examining equity: A multidimensional framework for assessing equity in payments for ecosystem services. Environ. Sci. Policy 2012, 33, 416-427.

7. Luttrell, C.; Loft, L.; Gebara, M.F.; Kweka, D.; Brockhaus, M.; Angelsen, A.; Sunderlin, W.D. Who should benefit from REDD+? Rationales and realities. Ecol. Soc. 2013, 18, 52.

8. Peskett, L.; Huberman, D.; Bowen-Jones, E.; Guy, E. Making REDD Work for the Poor; World Bank: Washington, DC, USA, 2008.

9. Lawlor, K.; Weinthal, E.; Olander, L. Institutions and policies to protect rural livelihoods in REDD+. Global Environ. Polit. 2010, 10, 1-11.

10. Pokorny, B.; Scholz, I.; de Jong, W. REDD+ for the poor or the poor for REDD+? About the limitations of environmental policies in the Amazon and the potential of achieving environmental goals through pro-poor policies. Ecol. Soc. 2013, 18, 3.

11. Myers, N.; Mittermeier, R.A.; Mittermeier, C.G.; da Fonseca, G.A.B.; Kent, J. Biodiversity hotspots for conservation priorities. Nature 2000, 403, 853-858.

12. Shepherd, A.; Mitchell, T.; Lewis, K.; Lenhardt, A.; Jones, L.; Scott, L.; Muir-Wood, R. The Geography of Poverty, Disasters and Climate Extremes in 2030; ODI: London, UK, 2013; p. 72.

13. Miller, D.C.; Agrawal, A.; Roberts, J.T. Biodiversity, governance, and the allocation of international aid for conservation. Conserv. Lett. 2012, 6, 12-20.

14. ONE. Evolution de la Couverture de Forêts Naturelles à Madagascar 2005-2010; Office National de l'Environnement, Ministère de l'Environnement et des Forêts, Conservation International, Foiben-Taosarintanin'i Madagasikara, Madagascar National Park: Antananarivo, Madagascar, 2013.

15. FCPF. R-pp: Proposition des Mesures Pour L'etat de Préparation-Madagascar; Banque Mondiale: Antananarivo, Madagascar, 2013.

16. Aubert, S.; Razafiarison, S.; Bertrand, A. Déforestation et Systèmes Agraires à Madagascar: Les Dynamiques des Tavy sur la Côte Orientale; CIRAD: Montpellier, France, 2003; p. 210.

17. Pollini, J. Slash-and-burn cultivation and deforestation in the Malagasy rain forests: Representations and realities. Ph.D. Thesis, Cornell University, Ithaca, NY, USA, 2007.

18. Kull, C.A. The evolution of conservation efforts in Madagascar. Int. Environ. Aff. 1996, 8, 50-86.

19. Desbureaux S. (Centre d'Etudes et de Recherches sur le Développement International, University of Auvergne, Auvergne, France). Personal communication, 2014.

20. Ollagnon, H. Une approche patrimoniale du milieu naturel. In Du Rural à L'environnement-la Question de la Nature Aujourd'hui; Jollivet, M., Mathieu, N., Eds.; L'Harmattan: Paris, France, 1989; pp. 258-268. 
21. Weber, J. Conservation, développement et coordination: Peut-on gérer biologiquement le social? In Colloque Panafricain. Gestion Communautaire des Ressources Naturelles Renouvelables et Developpement Durable; CIFOR: Harare, Zimbabwe, 1996.

22. Ostrom, E. Governing the Commons: The Evolution of Institutions for Collective Action; Cambridge University Press: Cambridge, UK, 1990.

23. Edmunds, D.; Wollenberg, E. Local Forest Management: The Impacts of Devolution Policies; Earthscan: London, UK, 2003; p. 224.

24. Blanc-Pamard, C.; Rakoto Ramiarantsoa, H. Normes environnementales, transferts de gestion et recompositions territoriales en pays Betsileo (Madagascar). Nat. Sci. Soc. 2007, 15, 253-268.

25. Hockley, N.J.; Andriamarovololona, M.M. The Economics of Community Forest Management in Madagascar: Is There a Free Lunch? An Analysis of Transfert de Gestion; USAID: Washington, DC, USA, 2007.

26. Antona, M.; Motte-Biénabe, E.; Salles, J.-M.; Péchard, G. Rights transfers in Madagascar biodiversity policies: Achievements and significance. Environ. Dev. Econ. 2004, 9, 825-847.

27. WCS. Makira REDD+ project. Available online: http://www.wcs.org/conservation-challenges/ climate-change/forest-conservation-and-carbon-markets/makira-carbon-company.aspx (accessed on 6 September 2014).

28. Conservation International. Center for Environmental Leadership in Business. Available online: $\mathrm{http} / /$ www.conservation.org/global/celb/Pages/main.aspx (accessed on 6 September 2014).

29. Burren, C. (WCS climate change technical advisor in Madagascar, Antananarivo, Madagascar). Personal communication, 2014.

30. Pascual, U.; Muradian, R.; Rodriguez, L.C.; Duraiappah, A. Exploring the links between equity and efficiency in payments for environmental services: A conceptual approach. Ecol. Econ. 2010, 69, 1237-1244.

31. Rawls, J. A Theory of Justice; Belknap Press: Cambridge, MA, USA, 1999.

32. WCS. Makira Forest Protected Area Project Design Document; WCS: New York, NY, USA, 2011.

33. Birkinshaw, C.; Randrianjanahary, M. The effects of cyclone Hudah on the forest of Masoala peninsula, Madagascar. Madag. Conserv. Dev. 2007, 2, 17-20.

34. WCS. Makira Forest Protected Area Project Design Document. For Submission to Smartwood Program, Rainforest Alliance, Following Climate, Community and Biodiversity (CCB) Standards Second Edition; WCS: New York, NY, USA, 2012.

35. Styger, E.; Fernandes, E.C.M.; Rakotondramasy, H.M.; Rajaobelinirina, E. Degrading uplands in the rainforest region of Madagascar: Fallow biomass, nutrient stocks, and soil nutrient availability. Agrofor. Syst. 2009, 77, 107-122.

36. Locatelli, B. Pression démographique et construction du paysage rural des tropiques humides l'exemple de Mananara (Madagascar). Ph.D. Thesis, Paris Institute of Technology for life, food and environmental sciences (AgroParisTech), Montpellier, France, 2000.

37. Styger, E.; Rakotondramasy, H.M.; Pfeffer, M.J.; Fernandes, E.; Bates, D.M. Influence of slash-and-burn farming practices on fallow succession and land degradation in the rainforest region of Madagascar. Agric. Ecosyst. Environ. 2007, 119, 257-269.

38. Isnard, H. La colonisation agricole à Madagascar. J. Alp. Res. 1951, 39, 97-125. 
39. Charbonnier, B. Limites et dynamique coutumières dans la forêt classée d'Ambohilero, à l'intérieur de la cuvette de Didy, sud est d'Ambatondrazaka. Master's Thesis, Ecole nationale du genie rural, des eaux et des forêts (ENGREF), Montpellier, France, 1998.

40. Ribot, J.C.; Peluso, N.L. A theory of access. Rural Sociol. 2003, 68, 153-181.

41. Blanc-Pamard, C.; Fauroux, E. L'illusion participative: Exemples ouest-malgaches. Autrepart 2004, 31, 1-19.

42. Delille, H. Perceptions et Stratégies D’Adaptation Paysannes Face aux Changements Climatiques à Madagascar; Agronomes et vétérinaires sans frontières (AVSF): Antananarivo, Madagascar, 2011.

43. Pierre Bernard, A.; Ramboarison, R.; Randrianarison, L.; Rondro-Harisoa, L. Dimensions Structurelles de la Libéralisation Pour L'Agriculture et le Développement Rural; APB Consulting: Antananarivo, Madagascar, 2007.

44. Judicaël (WCS development activities coordinator, Maroantsetra, Madagascar). Personal communication, 2012.

45. Wildlife Conservation Society, Système des Aires Protégées de Madagascar; Ministère de l'Environnement et des Forêts. Plan de Sauvegarde Sociale et Environnementale (PSSE)-Parc Naturel de Makira; Ministère de l'Environnement et des Forêts, Système des Aires Protégées de Madagascar, Wildlife Conservation Society: Antananarivo, Madagascar, 2013.

46. Karsenty, A. Contrat et gestion patrimoniale. In Economie Institutionnelle et Agriculture/ Institutional Economics and Agriculture. Actes du Xiiiième Seminaire D'économie Rurale 7,8,9 Septembre 1992; Griffon, M., Ed.; CIRAD: Montpellier, France, 1994; pp. 141-148.

47. Blanc-Pamard, C. La gestion contractualisée des forêts en pays betsiléo et tanala (Madagascar): Un dispositif dissymétrique. Les. Cahiers d'Outre Mer. 2012, 1, 47-83.

48. Jaozandry, J-J. (Director of Makira Natural Park, Maroantsetra, Madagascar). Personal communication, 2012.

49. Desbureaux, S.; Brimont, L. Between economic loss and social identity: The multi-dimensional cost of avoiding deforestation in eastern Madagascar. In XXXI Journées de la Microéconomie Appliquée; CERDI: Clermont-Ferrand, France, 2014.

50. Carter, M.R.; Little, P.D.; Mogues, T.; Negatu, W. Poverty traps and natural disasters in Ethiopia and Honduras. World Dev. 2007, 35, 835-856.

51. Brimont, L. Le coût de la Réduction des Emissions issues de la Déforestation et de la Dégradation des forêts (REDD+) à Madagascar. Ph.D. Thesis, Paris Institute of Technology for life, food and environmental sciences (AgroParisTech), Montpellier, France, 2014.

52. Husson, O.; Castella, J.-C.; Tuan, C.; Naudin, K. Diagnostic agronomique limitant le rendement du riz pluvial de montagne dans le nord du Vietnam. Cahiers Agric. 2004, 13, 421-428.

53. Blondel, N. (Former WCS regional representative in Maroantsetra, Antananarivo, Madagascar). Personal communication, 2012.

54. WCS. Plan D'aménagement et de Gestion de L'aire Protégée Makira; WCS: Antananarivo, Madagascar, 2011.

55. Messerli, P. Opportunities for agrobiological resource management in a region of slash-and-burn cultivation. A case study in the Beforona region, on the eastern escarpment of Madagascar. In Agrobiological Management of Soils and Cropping Systems; CIRAD: Montpellier, France, 1999. 
56. Carter, M.R. Investir pour innover en monde rural. Afr. Contemp. 2009, 1, 151-170.

57. Karsenty, A. Paiements pour services environnementaux et développement: Coupler incitation à la conservation et investissement. Available online: https://hal.archives-ouvertes.fr/hal-00723556/ (accessed on 6 September 2014).

58. Hourcade, J.-C.; Shukla, P.R.; Mathy, S. Cutting the Climate-Development Gordian Knot-Economic Options in A Politically Constrained World; CIRED: Paris, France, 2005.

(C) 2015 by the authors; licensee MDPI, Basel, Switzerland. This article is an open access article distributed under the terms and conditions of the Creative Commons Attribution license (http://creativecommons.org/licenses/by/4.0/) 